\title{
Halal Product: New Market Opportunity in Challenging the Industrial Revolution 4.0
}

\author{
Arifuddin Ahmad ${ }^{1}$, Tasmin Tangngareng ${ }^{2}$, Amrullah Harun $^{3}$, Mashuri Masri ${ }^{4}$ \\ \{ arifuddin.ahmad@uin-alauddin.ac.id ${ }^{1}$, tasmin.tangngareng@uin-alauddin.ac.id ${ }^{2}$, \\ arul.th2@gmail.com ${ }^{3}$, mashuri.masri@uin-alauddin.ac.id $\left.{ }^{4}\right\}$ \\ ${ }^{12}$ Department of Hadith, Faculty of Usul al-Din, Philosophy, and Politic, Universitas Islam \\ Negeri Alauddin Makassar, Indonesia. 92113 \\ ${ }^{3}$ Dirasat Islamiyah, Universitas Islam Negeri Alauddin Makassar, Indonesia. 92113 \\ ${ }^{4}$ Department of Biology, Faculty of Science and Technology, Universitas Islam Negeri \\ Alauddin Makassar, Indonesia. 92113
}

\begin{abstract}
Most people in Indonesia is Islam and becomes the market target for halal label product, either in food, tourism, to the pharmaceutical and cosmetic. This study aims to analyze development of halal products in the world and Indonesia as new market opportunity in face industrial revolution 4.0. The result showed that Indonesia has a big opportunity as a provider of halal product in the world with become top ten country of halal product expenditure. Labeling and certificating of halal products include food, tourism, cosmetics, and medicines is the obligation of the government and society which need competent human resources to support the continued growth of this industry.
\end{abstract}

Keywords: halal product, industrial revolution 4.0, expenditure

\section{Introduction}

Halal product in Industry 4.0 era becomes a sensitive discussion, especially in Muslim society. Most of Indonesian people is Islam [1] and becomes high consumer market potency for halal product, from food and tourism, pharmaceuticals to cosmetic as a life style [2]. The producer have many ways in this industry era to prepare and distribute their product through the machine processing. Therefore, in some cases, the producers are not aware on legitimacy product for Muslim [3]. The religion of Islam determine an absolute legitimacy and goodness of a product, because it will influence Muslim personality, either physically or spiritually. Quran and hadith have explicitly explained the halal or haram product based on the material, process, and outcome, known by haram lizatihi and haram ligairihi.

The emergence of new technology in the face of the industrial revolution 4.0 resulted in extraordinary changes in various disciplines, especially in science and technology which played a role of 75\% [4][5][6]. Merging the physical and digital worlds is a dilemma for the halal label of a product. Collaborative knowledge becomes very important, mainly in processing of research commercialization which appropriate, safe, and applied for all things in this life, 
includes in working activity, especially for the product (food, beverage, tourism, pharmaceutical, and cosmetic).

Thailand has established as the world's halal food industry of $24 \%$ with income of GDP per capita [7][8]. Australia has produced and exported $66 \%$ of halal meat with certificates issued by Islamic Coordinating Council of Victoria dan Supreme Islamic Council of Halal Meat in Australia Inc (NSW) [9][10]. South Korea which is famous for beauty brand also dominates the world's halal cosmetics industry by $13 \%$ [11], while $18 \%$ the halal garment and textile sector is dominated by China.

Consequently, a comprehensive understanding requires in product selection. The integration hadith on science explained a specific limitation between halal and haram is syubhat or shubha (doubtful/obscurity). Many people have no knowledge about the shubha. Based on the background, this paper will bring out that halal product as opportunity market againts the challenge of industrial revolution 4.0 based on hadith integrated science.

\section{Material and Methods}

The study of halal products in Indonesia is carried out in the following stages. First, tracing information on print and electronic media and literature on the development of halal products in the world and Indonesia. Second, collecting data of government policies on halal products. Third, analysis by describing data in general and based on hadith.

\section{Results and Discussion}

The potential of global halal products provides various challenges and opportunities. The potential of halal products is essentially not only for Muslim countries or populations, also for consumers who have a preference for healthy and quality halal products. The potential of the global muslim market for halal product requirements is outlined in the following table:

Table 1. Ten countries with halal food expenditure [12][13]

\begin{tabular}{clcc}
\hline No. & Country & $\begin{array}{c}\text { Amount of } \\
\text { expenditure (US \$) }\end{array}$ & $\begin{array}{c}\text { Percentage of world } \\
\text { muslim population }\end{array}$ \\
\hline 1 & Indonesia & $170 \mathrm{bn}$ & $12.6 \%$ \\
\hline 2 & Turkey & $127 \mathrm{bn}$ & $4.5 \%$ \\
\hline 3 & Pakistan & $118 \mathrm{bn}$ & $10.5 \%$ \\
\hline 4 & Egypt & $86 \mathrm{bn}$ & $4.8 \%$ \\
\hline 5 & Bangladesh & 76 bn & $8.4 \%$ \\
\hline 6 & Iran & $63 \mathrm{bn}$ & $4.6 \%$ \\
\hline 7 & Saudi Arabia & $52 \mathrm{bn}$ & $4.8 \%$ \\
\hline 8 & Nigeria & $47 \mathrm{bn}$ & $8 \%$ \\
\hline 9 & Russia & $41 \mathrm{bn}$ & $11 \%$ \\
\hline 10 & India & $38 \mathrm{bn}$ & \\
\hline
\end{tabular}


Indonesia has spending in aggregate US\$170 billion across the halal food sectors with 215 million muslims representing $12.6 \%$ of muslim population in the world (Table 1). The large share of halal products market is due to the majority of Indonesia's population being Muslim. The demand for halal products is very high compared to other countries. Manufacturers who will market the halal products will not experience difficulties. This sector will become a major sector consistently and sustainably in a long period, also as a catalyst to develop other potential sectors.

The fundamental of halal and haram substance has been a clear boundary (either in activity or goods for consumption). However, there is shubha (obscurity) between both of two matters without a clear legitimation for most of people and sound a warning to careful from shubha. Additionally, halal and haram substances will also influence the condition of soul.

The hadith matters has three categories. First, halal matter with a clear case in legitimacy, such as, bread, fruit, oil, honey and so on. Second, haram matter with clear legitimacy, such as khamr or wine, pig, carcass, gossip, and so on. Third, shubha matter without a clear information, either it is halal or haram. As a result, the hadith above has three substances: 1. Halal substance with a clear argumentation or daleel that allowed by Quran and hadith, 2. Haram substance that forbidden clearly in Quran and hadith, and 3. Shubha substances without legitimacy or forbidden information from Quran and hadith. Therefore, all things on this earth is halal for man to consume (food and beverage) as long as no legitimacy from sharia or Islamic law (Quran, hadith, ijma, or qiyas) with prohibition rule. We can understand that halal food in Islam includes a good matter, based on material/substance only without a bad thing inside.

Indonesia has an institution that handles halal products, namely the Council of Indonesian Ulama (Majelis Ulama Indonesia, MUI). The MUI has a fatwa commission called the Institute for Food, Drug and Cosmetics Studies of the MUI (LPPOM MUI) which conducts studies and maintains the halal products circulating in the community. The Ministry of Religion of the Republic of Indonesia took over halal certification in 2017 by establishing a Product Assurance Agency (BPJPH). This agency will facilitate the administration process of halal certification, which involves receiving all applications, collecting fees, and issuing certificates [14]. Providing halal and safe food is a prospective business, because halal labels can invite loyal customers who are not only interested in Muslims but also non-Muslim communities. The existence of halal certification is not only aimed at giving inner peace to Muslims but also the calm of production for businesses.

Table 2. Ten countries with muslim travel expenditure [12][13]

\begin{tabular}{clcc}
\hline No. & Country & \multicolumn{1}{c}{$\begin{array}{c}\text { Amount of } \\
\text { expenditure (US \$) }\end{array}$} & $\begin{array}{c}\text { Percentage of world } \\
\text { muslim population }\end{array}$ \\
\hline 1 & Saudi Arabia & 21 bn & $2 \%$ \\
\hline 2 & UAE & 16 bn & $0.2 \%$ \\
\hline 3 & Qatar & 13 bn & $0.1 \%$ \\
\hline 4 & Kuwait & 10 bn & $0.2 \%$ \\
\hline 5 & Indonesia & 10 bn & $12.6 \%$ \\
\hline 6 & Iran & 8 bn & $4.6 \%$ \\
\hline 7 & Malaysia & 7 bn & $8 \%$ \\
\hline 8 & Russia & 7 bn & $4.5 \%$ \\
\hline 9 & Turkey & 6 bn & $4.8 \%$ \\
\hline 10 & Nigeria & 6 bn & \\
\hline
\end{tabular}


Indonesia become top five country with muslim travel expenditure, spending 10 billion US\$, highest compared to other Asian countries (Table 2). The concept of halal tourism that can be developed is the Sharia tourism concept which the integration of Islamic values into all aspects of tourism activities, from accommodation, restaurants, to tourism activities [15][16]. Hence, the largest Muslim population in the world, Indonesia has ability to become a market for the Sharia tourism industry in the world and this should be realized by tourism businesses. The development of sustainable Sharia tourism will be able to provide a significant economic contribution to all economic actors involved. Absorption of labor in this sector is also quite significant thus creates an efficient workforce.

Table 3. Ten countries with muslim cosmetics expenditure [12][13]

\begin{tabular}{clcc}
\hline No. & Country & $\begin{array}{c}\text { Amount of } \\
\text { expenditure (US \$) }\end{array}$ & $\begin{array}{c}\text { Percentage of world } \\
\text { muslim population }\end{array}$ \\
\hline 1 & India & 5.4 bn & $11 \%$ \\
\hline 2 & Indonesia & $3.9 \mathrm{bn}$ & $12.6 \%$ \\
\hline 3 & Russia & $3.6 \mathrm{bn}$ & $8 \%$ \\
\hline 4 & Turkey & $3.4 \mathrm{bn}$ & $4.5 \%$ \\
\hline 5 & Malaysia & $3.1 \mathrm{bn}$ & $2 \%$ \\
\hline 6 & Bangladesh & $2.9 \mathrm{bn}$ & $1.9 \%$ \\
\hline 7 & Iraq & $2.2 \mathrm{bn}$ & $0.5 \%$ \\
\hline 8 & Kazakhstan & $2.1 \mathrm{bn}$ & $0.3 \%$ \\
\hline 9 & France & $1.8 \mathrm{bn}$ & $4.6 \%$ \\
\hline 10 & Iran & $1.8 \mathrm{bn}$ & \\
\hline
\end{tabular}

As the highest percentage of world population, Indonesia become the top two of country with muslim cosmetics expenditure (Table 3), 1.5 bn difference below India. Halal cosmetics have become a major requirement that is always sought by Muslim women. The growth in demand for halal products which shows a positive trend, makes Indonesia a potential market for cosmetic products. The segment of young women is usually targeted the main market for cosmetic producers. At this age level, consumers' awareness to appear attractive tends to be higher, driven by more social interactions compared to other ages [17]. Muslim consumers who have high religiosity generally tend to have a higher awareness of consuming halal products. Halal and goodness of a product is not only on the material substance and acquisition method. The product must also concern on the process method. The product must not combine with shubha material or definitely haram in material, as explained in the Prophet Muhammad (PBUH) hadith on bread dough with water from Al-Hijr hill. Halal cosmetics brands also face both challenges and opportunities as natural, organic, plant-based cosmetics, and avoid ingredients that are non-religiously permissible: porcine, cochineal and non-halal slaughtered animals.

Table 4. Ten countries with muslim pharmaceuticals expenditure [12][13]

\begin{tabular}{clcc}
\hline No. & Country & $\begin{array}{c}\text { Amount of } \\
\text { expenditure (US \$) }\end{array}$ & $\begin{array}{c}\text { Percentage of world } \\
\text { muslim population }\end{array}$ \\
\hline 1 & Turkey & $10.3 \mathrm{bn}$ & $4.5 \%$ \\
\hline 2 & Saudi Arabia & $7.5 \mathrm{bn}$ & $2 \%$ \\
\hline 3 & United States & $6.8 \mathrm{bn}$ & $0.2 \%$ \\
\hline 4 & Indonesia & $5.2 \mathrm{bn}$ & $12.6 \%$ \\
\hline
\end{tabular}




\begin{tabular}{clcc}
\hline 5 & Algeria & 4 bn & $2.2 \%$ \\
\hline 6 & Russia & 3 bn & $8 \%$ \\
\hline 7 & Iran & 3 bn & $4.6 \%$ \\
\hline 8 & Germany & 2.7 bn & $0.2 \%$ \\
\hline 9 & Pakistan & 2.7 bn & $10.5 \%$ \\
\hline 10 & France & 2.5 bn & $0.3 \%$
\end{tabular}

Demand for preventative medicine as well as a more healthy and halal lifestyle, driven by Muslim in Indonesia by spending 5.2 billion US\$ in pharmaceuticals expenditure (Table 4). Consumers of halal medicine in Indonesia are dominated by Muslims. The halal status of the drug is a demand in the ethics of drug consumption. The application of halal drug production processes will increase consumer acceptance of these products, which will have an impact on increasing sales [18]. In addition to the aspects of production, the aspects of packaging, storage and distribution that are able to guarantee the prevention of cross contamination of illicit ingredients into halal drugs are an urgency in consumer acceptance.

Specifically, pharmaceutical consumption is extremely urgent then food or cosmetic application. Sometimes, chemical substance in drug with biology tissue influence creates a temporary minded from the patient to consume the drugs, because a strong desire to recovering their health. In addition, most people only concern to the function and drug performance without concerning the substances inside the material (halal or haram) for rapid recovery reason.

There are many methods to know which product that will create a damage and harm to the consumer in this industry era presently. Halal and composition tag are compulsory include for the producer. So, the customers may concern on halal or haram of product and selecting and deciding the product compatibility for themselves. When buyer found no tag attach in the product then it would be a temporary conclusion for the consumer that the product is "ambiguous" in terms of material substance. Therefore, according to hadith of the Prophet Muhammad (PBUH), those ambiguous product category status is shubha or unknown. Muslim is better to avoid an ambiguous matter status, halal or haram.

Labeling halal products consisting of food, tourism, cosmetics and pharmaceuticals that circulate in Indonesian society is the duty of the government and society as a control over a lifestyle [19] that safeguards religious values. In facing the global market of industrial revolution 4.0, the implementation of the halal product system aims to provide comfort, security, safety, and certainty of the availability of halal products for the public in consuming and using products, as well as increasing added value for businesses to produce and sell halal products.

\section{Conclusion}

All available natural resource basically is halal for food or drink as long as no prohibition daleel in Quran, hadith, ijma, and qiyas. Indonesia has a big opportunity as a provider of halal product in the world. Halal product solution against the industrial revolution 4.0 challenge according to hadith is to ensure the legitimacy and goodness of product. which acquire from halal tag and product composition tag. Labeling and certificating of halal products consisting of food, tourism, cosmetics and medicines is the obligation of the government and society. In addition, competent human resources are needed to support the continued growth of this industry. 


\section{References}

[1] A. Zainuri, "Keberagaman komunitas muslim dan Islam keindonesiaan," Medina-Te J. Stud. Islam, vol. 13, no. 1, pp. 1-8, 2017.

[2] D. R. Indika and S. Lainufar, "Eksplorasi sikap konsumen terhadap kosmetik halal (studi kasus:wardah)," Performa J. Manaj. dan Bisnis, vol. XIII, no. 1, pp. 55-64, 2016.

[3] A. E. Wibowo, "Analisis Prilaku Konsumen dalam Memilih Produk Kosmetik yang Ramah Lingkungan," J. Ilm. Manaj. Univ. Puter. Batam, vol. 5, no. 1, pp. 13-25, 2017.

[4] M. Warschauer and T. Warschauer, "New Technology and Digital Worlds: Analyzing Evidence of Equity in Access, Use, and Outcomes," Rev. Res. Educ., vol. 34, no. 1, pp. 179-225, 2010.

[5] Y. Lu, "Industry 4.0: A survey on technologies, applications and open research issues," J. Ind. Inf. Integr., vol. 6, no. 1, pp. 1-10, 2017.

[6] T. Zimmermann, Industry 4.0: Nothing Is More Steady Than Change. Pennsylvania: IGI Global, 2018.

[7] R. Nurrachmi, "The Global Development of Halal Food Industry: A Survey," Tazkia Islam. Financ. Bus. Rev., vol. 11, no. 1, pp. 39-56, 2017.

[8] M. S. A. M. Nawawi et al., "Halal Food Industry in Thailand: History, Prospects, and Challenges," in The 1st international halal management conference (IHMC), 2017, pp. 302-307.

[9] M. H. Zulfakar, F. Jie, and C. Chan, "Critical success factors for a successful implementation of halal red meat supply chain in Australia: meat processor's perspective," in 11th ANZAM Operations, Supply Chain and Services Management Symposium, 2013, pp. 1-15.

[10] M. H. Zulfakar, C. Chan, and F. Jie, "Institutional forces on Australian halal meat supply chain (AHMSC) operations," J. Islam. Mark., vol. 9, no. 1, pp. 80-98, 2018.

[11] H. Elasrag, "Halal Industry: Key Challenges and Opportunities," vol. 69631, pp. 1-34, 2016.

[12] GIE, "An Inclusive Ethical Economy: State of the Global Islamic Economy, Report 2018/19," Dubai, 2018.

[13] Pew Research Center, "The countries with the 10 largest Christian populations and the 10 largest Muslim populations," Washington, 2019.

[14] A. Fithriana and R. P. Kusuma, "Implementasi Kebijakan Pangan Halal Indonesia: Keunggulan Kompetitif Dalam Tren Pangan Halal Di Asia Tenggara," Glob. Insight J., vol. 3, no. 1, pp. 1$18,2018$.

[15] K. G. Widagdyo, “Analisis pasar pariwisata halal Indonesia,” J. Tauhidinomics, vol. 1, no. 1, pp. 73-80, 2015.

[16] A. S. Hidayat and M. Siradj, "Sertifikasi halal dan sertifikasi non halal pada produk pangan industri," Ahkam, vol. XV, no. 2, pp. 199-210, 2015.

[17] N. H. Endah, "Perilaku pembelian kosmetik berlabel halal oleh konsumen Indonesia," J. Ekon. dan Pembang., vol. 22, no. 1, pp. 11-25, 2014.

[18] R. Ranasasmita and A. P. Roswiem, "Kehalalan produk obat-obatan, terutama obat herbal," in Simposium Penelitian Bahan Obat Alam XIV, 2009, pp. 552-559.

[19] W. Adisasmito, "Analisis kebijakan nasional MUI dan POM dalam labeling obat dan makanan," Jakarta, 2008 